\title{
When William Came: A Prophetic Propaganda War
}

\author{
Satoru Fukamachi (D)
}

check for updates

Citation: Fukamachi, Satoru. 2021. When William Came: A Prophetic Propaganda War. Humanities 10: 32. https://doi.org/10.3390/h10010032

Received: 15 December 2020

Accepted: 8 February 2021

Published: 20 February 2021

Publisher's Note: MDPI stays neutral with regard to jurisdictional claims in published maps and institutional affiliations.

Copyright: (C) 2021 by the author. Licensee MDPI, Basel, Switzerland. This article is an open access article distributed under the terms and conditions of the Creative Commons Attribution (CC BY) license (https:/ / creativecommons.org/licenses/by/ $4.0 /)$.
Department of Literature, Doho Univeristy, Nagoya 453-8540, Japan; fsatoru@doho.ac.jp

\begin{abstract}
When William Came by Saki (H. H. Munro) is a unique novel in the genre of invasion literature. Starting after a fictional war between Britain and Germany, it depicts no scenes of invasion. Recently, there have been studies from the perspective of how Munro and other authors in the genre viewed Germany and Britain. Some studies also refer to Munro's deliberate lack of depiction of the war. However, it seems that no studies have looked into the reasons why the war is not depicted. This paper argues that the story is not about showing British military unpreparedness but about how psychological weapons work. It could even be said that depictions of war would distract from the focus on propaganda and its effect on people. Considering this work as being about a British and German propaganda war opens up a new perspective that is different from previous studies. When William Came is a work that points out Britain's unpreparedness for psychological war by imagining and detailing possible propaganda strategies. It has been said that the novel's ending is unsatisfactory, as it only ends up showing the potential for youth resistance. However, if it is understood that this novel, from beginning to end, is about a propaganda battle, a war that is fought under the surface, then the final chapter can also be understood as a thrilling one.
\end{abstract}

Keywords: Saki; Hector Hugh Munro; When William Came; propaganda

\section{Introduction}

Hector Hugh Munro (1870-1916), who used the pen name Saki, wrote When William Came: A Story of London under Hohenzollerns (1913) just a year before the First World War (Saki 1914). The story is about a fictional London under the reign of William II. The protagonist, Yeovil, and his wife, Sicily, have different feelings about Germany. Yeovil is quietly resistant to the Germans, while Sicily sees them not as an enemy but as an opportunity for her to rise in the social world. As Germany enacts various laws to consolidate its control over Britain, the British people gradually become more and more obedient to Germany.

This story falls into the genre of so-called invasion literature. Because of the nearfuture prophetic content, stories of invasion tend to be forgotten once the future they refer to has arrived. Munro seemed to be aware of the nature of such works and sent a letter to a certain Mr. Willet at the publishing company, John Lane. Munro urged him to hasten the publication of the book so that it would not be more appropriately titled 'When William Went' (Byrne 2007, p. 121). However, unlike many of the forgotten stories in the genre, this novel is still in print. It is rare that a story presenting the danger of German invasion before the First World War is being read today.

The novel was first published in the Japanese language in 2019 (Fukamachi 2019) and reviewed in the Asahi Shimbun (Kadoi 2019, p. 9) and other media outlets. I believe that discussing this work as an invasion story will contribute not only to the study of the genre, but also to the study of Munro's works. Another characteristic of this novel is that it does not depict the war itself. Recently, there have been studies from the perspective of how Munro and other authors in the genre viewed Germany and Britain, including those by Bayley (2019) and Laurie-Fletcher (2019).

Referring to Munro's deliberate lack of depiction of the war is not new. As Harry Wood points out in his study, '[I]n bypassing invasion to analyse the consequences of British military defeat, Munro offered the most damning of all Edwardian invasion narratives' 
(Wood 2014, p. 197). This quote rightly states that the novel is better for not depicting the war, and finding such example is not hard at all. However, it seems that no studies have looked into the reasons why the war is not depicted.

William Le Queux's The Invasion of 1910, with a full account of the Siege of London (Le Queux 1906) is a particularly famous work of invasion fiction in the same period. This detailed description of the German invasion, pointing out the inadequacies of British defence policy, features frequent scenes of civilians being brutally slaughtered and other violence that likely provoked hostility in British readers towards Germany at the time. H. G. Wells's The War of the Worlds (Wells 1898) describes how the Martians attack the humans, which takes up a large part of the story. Moreover, Wodehouse's The Swoop! or How Clarence Saved England (Wodehouse 1909), which can be positioned as a comedic antithesis to the invasion stories, is about the powers invading Britain en masse and how it happens. It proves that such a ridiculous prediction can be made based on a non-zero chance of invasion. It was obvious, even at the time, that invading scenes were regarded as the most exciting feature of the genre. Nevertheless, unlike his contemporaries, Munro seemed to have no intention of writing battle scenes but still ventured into the genre.

In this paper, I will attempt to clarify why he skipped the war depictions. Firstly, I will analyse why Munro entirely omitted war scenes and why the setting had to be post-war London by challenging the current discourse, which holds that Munro tried to depict a morally degraded London. Secondly, I will further analyse how the absence of battle scenes can work effectively, especially on the pro-argument of conscription, which seems the main theme of the story. Finally, I will hypothesise that Munro is actually depicting battles-not physical battles, but psychological. To do so, I will show how the battles are described. Upon publishing this work, Munro was criticised as 'militaristic, arrogant and xenophobic' (Wood 2014, p. 194). This kind of labelling could have been easily anticipated. I hope this study will clarify why Munro, even knowing this risk, wrote a work of invasion literature.

\section{Why Did Munro Avoid the War?}

When William Came has no war scenes; however, it is hard to think that Munro was not able to describe them. As a correspondent for the Morning Post, he was sent to the Balkans and Russia for four years. He witnessed the first Balkan War and the first Russian Revolution in Russia from its beginning and saw many massacres (Byrne 2007, p. 87). He even witnessed a shootout in St. Petersburg, in which thousands of people were killed (Byrne 2007, p. 90). Thus, as a newspaper reporter, Munro was never clueless as to how war is fought, but in When William Came, he did not make use of his experience.

One possible answer might be that Munro tended to avoid depictions of violence. For example, in 'Sredni Vashtar' (Saki 1912, pp. 93-102), the protagonist, Conrad, sets a death trap and kills his guardian, Mrs. De Ropp, whom he hates with all his heart. However, when she is about to be killed, the narrator focuses on Conrad, and she is hidden from the reader. Her death is only hinted at in the description of the killer, a large weasel, with its blood-stained jaws coming out from the place where she is, and the servants, who scream at the sight. In another story, 'The Chaplet' (Saki 1912, pp. 111-18), the head chef of a restaurant kills the master of the orchestra because the chef is jealous of the master, who has attracted the attention of all the guests. The head chef puts the conductor's head in a soup bowl, but the cause of his death is described as ' $[w]$ hether the leader of the orchestra died from drowning by soup, or from the shock to his professional vanity, or was scalded to death, the doctors were never wholly able to agree' (Saki 1912, p. 118). Thus, death in Munro's stories tends to be either indirectly told or otherwise humorous, and it is strange that a writer who avoided portraying tragic deaths even considered writing a tragic defeat of Britain.

Because of his oblique view of the world, it may be naïve to assume that he simply wanted to write a story of invasion. However, the timing of his publication of the novel and the high demand for such stories just then might not be a coincidence. Byrne shows in quotes from various letters that Munro was financially challenged, and this also suggests 
that he needed to write a popular story (Byrne 2007, p. 121). Munro decided to become a professional writer sometime before the publication of When William Came, and he needed a commercially successful work. He also wrote a letter to his publisher, fearing the publication would come too late: 'The death or critical illness of the Kaiser would spoil the book's chances, and while "When William Went" would be a charmingly alliterative title, he would have to write an entirely new novel to fit it' (Byrne 2007, p. 121). What Munro was aware of at this point was the commercial value of the book as well as its expiry time. Publishing it after the German Emperor's death would spoil its novelty, and, even though it is fiction, would undermine some credibility in his prophecy, an element that should be present in an invasion story. His financial difficulty might have forced him to become a popular writer of the genre. Also, it can be thought that since previous invasion stories generally focused on the invasion and tended to depict the post-war situation in a macroscopic manner, he might have thought it would be interesting to focus on the post-war period instead.

However, I believe all the reasons mentioned above are not strong enough, because he discarded the most exciting feature of invasion literature: fearful and realistic depictions of an invading army. I also believe the current discourse holding that Munro was describing the moral decay of Edwardian people is only half right too. Because if he truly wanted to ironically point out the degeneration of the British, then there was no point, for example, of making it difficult for the Germans in the story to rule and control them, it would have been described as easy.

For authors whose main focus is on Britain's defence strategy, war means military conflict, but, for Munro, it is highly questionable if he saw it the same. For example, Eleanor Greymarten, an old woman in Chapter XIII, appears as a loser who has fallen from the ruling class after the war. She urges Yeovil to make his choice to be a fighter or a servant of the new ruler. He replies that he will wait to gather information and an opportunity to fight back. When Yeovil expresses this calm and rational thought, she says, 'Time is on their side, not ours. It is the young people we must fight for now, if they are ever to fight for us' (p. 221). She also tells him, 'I would awaken or keep alive in their [young people's] memory the things that we have been, the grand, brave things that some of our race have done, and I would stir up a longing, a determination for the future that we must win back' (p. 222). No military soldier appears anywhere in the scene here. However, Eleanor, who is described as a loser, is still fighting. She encourages Yeovil to fight for the country. She does not give up her hope to win back Britain even after the thorough military defeat. For her, the war has not ended.

Another example is the British widow, Mrs. Kerrick, in Chapter XVI, who moved to a colony because she could not hoist the Union flag proudly. The humble act of hoisting the flag every morning at sunrise is not only to console the minds of the neighbouring Britons, who also emigrated there, but also to inspire the children. She is silently fighting for British pride.

Since Britain is thoroughly defeated, these women's efforts seem to be meaningless. Their activities can be seen as a grassroots movement, but patriotism itself is not able to overcome victorious Germany. As Munro shows, it is not enough when one passenger in a train talks about the defeat of Germany in this manner:

The last war wasn't a war, it was a snap. We weren't prepared and they were a highly civilised race like ours, with the record that we've had for leading the whole world, is not going to be held under for long by a lot of damned sausageeating Germans. [O]ur sea-sovereignty hasn't slipped from us, and won't do, neither. There's the British Empire beyond the seas; Canada, Australia, New Zealand, East Africa.

He is portrayed as a patriot who is unable to face reality. He is blindly convinced that Britain has enough power to defeat Germany and believes that, with will and motivation, Britain can get out of this miserable situation. In response, Yeovil points out that Britain lacks 
battleships and cruisers, and when he explains that logically Britain cannot defeat Germany, his opponent calls Yeovil a half-hearted patriot and walks away. Upon encountering such a person, Yeovil laments, saying, 'England has never had any lack of patriots of that type' (p. 209). However, Yeovil himself, who hates German domination but indulges in hunting and other activities, does not seem to be depicted as a decent patriot. The difference between the patriotism of the fisherman and that of the two women seems not to be wide when it comes to thinking about how significant it is to the current situation. There is hardly a British character in this novel who considers themselves unpatriotic. Many of them consider themselves patriotic and embrace the German regime at the same time, and they plot their rise under Germanic London. Their argument may be summed up in the words of Cecily, who organises a big event to revitalise the social season that has been badly damaged by the defeat:

We may arrive at the position of being the dominant factor in that Empire impressing our national characteristics on it, and perhaps dictating its dynastic future and the whole trend of its policy. Such things have happened in history. Or we may become strong enough to throw off the foreign connection at a moment when it can be done effectually and advantageously. But meanwhile, it is necessary to preserve our industrial life and our social life, and for that reason, we must accommodate ourselves to present circumstances, however distasteful they may be. [I]f you will think things over a bit, you will see that the course I am following is the one dictated by sane patriotism.

(pp. 112-3)

Living such a way of life may be reasonable and unavoidable under the German occupation. Cecily strives for an important position in the upper class, and by securing that important position, she thinks she will be able to guide the German rulers. However, it is too naïve to hope that she can engage in any activity that would weaken Germany's influence in Britain. It is obvious that Cecily uses patriotism as a pretext for her ambition. Her efforts in society will not be beneficial for British independence, either in the short term or in the long term. While these various useless patriots appear on the scene, Germany makes an effective move to prevent Britain from ever rising up again.

\section{The Intention to Advocate for Conscription}

The most noticeable political agenda in this story is the compulsory military service in Britain. Munro creates a desirable situation in favour of promoting conscription without war scenes. The intention to promote conscription is seen first within the flashback described by Holham, a doctor and friend of Yeovil's, in Chapter III, 'The Metskie Tzar'. Holham explains that the Royal Navy and Army were being attacked at a time when the two forces were being divided up abroad. However, he blames British citizen soldiers for losing the war. This is told as follows:

Our half-trained men and our untrained men could not master the science of war at a moment's notice, and a moment's notice was all they got. The enemy were a nation apprenticed in arms, we had not deemed apprenticeship worth our while. There was courage enough running loose in the land, but it was like unharnessed electricity, it controlled no forces, it struck no blows.

(pp. 45-6)

This is exactly the kind of comment that is common in invasion novels such as The Battle of Dorking: Reminiscences of a Volunteer (Chesney 1871) and The Invasion of 1910 (Le Queux 1906). This passage, which refers to the differences in the strength of the British and German forces in terms of the skills of civilians, implies that the absence of conscription in Britain should be blamed. Throughout the novel, Holham's remarks on the war in this chapter are the only passages that reveal how the war is fought.

Unlike other European countries, Britain had no compulsory military service then, and has had a history of refusing to do so until now (except during the two World Wars). 
There was a notable rise in support for conscription in 1871, the year The Battle of Dorking (Chesney 1871) was published, just after the Franco-Prussian War (1870-1871). However, after the Second Boer War (1899-1902) and before the First World War, the public voices demanding conscription were the loudest. The fact that Munro himself joined the army the following year, and that Lord Roberts ${ }^{1}$ supported his work, reinforces the theory that this novel advocates for conscription (Atwood 2015). In this aspect, as Laurie-Fletcher says, this story is 'typical of most invasion stories' (Laurie-Fletcher 2019, p 38). However, later in the novel, Munro explains the necessity of conscription from a unique viewpoint. Like real British people at the time, the fictional British people in the London of the novel are proud of themselves for having managed to do without conscription, and as new laws are enacted and enforced one after another under the new regime, the characters in the story are prepared to accept that the German ruler will implement conscription. The people are worried about how much of a burden the law will impose on them. However, the emperor makes an unexpected decision:

The British born subjects of the Germanic Crown, inhabiting the islands of Great Britain and Ireland, had habituated themselves as a people to the disuse of arms and resolutely excluded military service and national training from their political system and daily life. Their judgment that they were unsuited as a race to bear arms and conform to military discipline was not to be set aside. Their new Overlord did not propose to do violence to their feelings and customs by requiring from them the personal military sacrifices and services which were rendered by his subjects German-born. Necessarily, a heavily differentiated scale of war taxation would fall on British taxpayers.

(pp. 187-88)

Because the British people disliked the idea of conscription so badly, they were thought to be unfit for soldiering. In addition to that, they are banned from carrying arms and maintaining volunteer corps and rifle clubs. The fictional Germans exploit the free will of the British to control them. Many of the Londoners have hated military service as a duty, and even though their wish is now being fulfilled, they show no signs of rejoicing. On the contrary, they are disappointed and confused:

Public anticipation had guessed at various forms of military service, aggressively irksome or tactfully lightened as the case might be, in any event, certain to be bitterly unpopular, and now there had come this contemptuous boon the enemy had called them [the British] in splenetic scorn long years ago-a nation of shopkeepers. Aye, something even below that level, a race of shopkeepers who were no longer a nation. A company of Bavarian infantry went by, in all the pomp and circumstance of martial array and the joyous swing of rapid rhythmic movement. A group of lads from the yea-shop clustered on the pavement and watched the troops go by, staring at a phrase of life in which they had no share.

(pp. 189-90)

In the minds of these men, like real British people, they believed that they were useful as soldiers but did not want to be soldiers and believed they had the right to choose. However, by this law, they are officially labelled useless as soldiers. Here, Munro shows the complete opposite idea to compulsory military service. For those who prefer not to be soldiers, not to have a right to refuse is a sad thing; however, being labelled as useless and refused from the military is humiliating. Moreover, they could not object to this law, not only because they were a subjugated people, but also because they had been publicly opposed to being soldiers. So, this part might have challenged the reader's imagination to see which was worse. Detailing the clause in the law could also reveal the viewpoint of masculine Germany; British men are seen as castrated.

1 Lord Roberts was a supervisor of Chesney in India. Their relationship is detailed in Rodney Atwood's 'Commander in Chief, India' in The Life of Field Marshal Lord Roberts (2015), pp. 135-60. 
Like Holham, a young clergyman in Chapter XI also holds a positive view of conscription, but from a different perspective. Yeovil meets him in a tea shop on the day the conscription law is announced:

Every now and then in the course of my work I have come across lads who were really drifting to the bad through the good qualities in them. A clean combative strain in their blood, and a natural turn for adventure, made the ordinary anaemic routine of shop or warehouse or factory almost unbearable for them. The only adventure that their surroundings offered them has been the adventure of practising mildly criminal misdeeds without getting landed in reformatories and prisons but think of it for those boys, who might have been marching along to the tap of the drum, with a laugh on their lips instead of Hell in their hearts.

(pp. 184-85)

In short, it is argued that becoming a soldier and completing military service is a social good and is good for the minds of young people, but this argument is one-sided, because no opposing view is expressed. Such an opinion at the time was well-supported, but represented a minority. The National Service League ${ }^{2}$ was growing in strength at the time (Stearn 2006). However, the prominent figures in the organisation included members of Parliament but no political party leaders (Johnson 2017, p. 214). The following examples illustrate how unpopular conscription was. The National Military Training Bill, proposed by Malcolm Kincaid-Smith, a Boer War veteran and Liberal MP, was rejected in 1908 by an overwhelming 250 to 34 votes. Afterwards, he sought a way to pass the draft quickly, hoping that voters would give him a boost, and he resigned as MP and tried to get reelected, but the voters refused to choose him (Johnson 2017, p. 215). So, it can be seen that compulsory military service was favoured by powerful legislators and also by the public. The clergyman's opinion on these youth is mirrored in the arguments of George R. F. Shee in The Briton's First Duty: The Case for Conscription (Shee 1901), which was one of the catalysts for the founding of the National Service League (Shee 1901, pp. ix-x). It is too convenient to think the young clergyman's opinion is coincidental with Shee's. Rather, it is reasonable to think that a pro-NSL viewpoint is positively presented there.

Unlike Chesney and others, who ironically described under-skilled citizen-soldiers and argued for the establishment of a universal military training system, Munro tries to persuade the reader from a different perspective. He does not resort to ordinary means of depicting the loss of life and property but appeals to the reader's pride.

Munro also places Britain and the characters in a hopelessly disadvantageous situation. However, the Germans are not certain if their rule can continue for a long time, as they see the people living in the land have not entirely accepted the new ruler. The ban on conscription is bold, but it is only one of the psychological battles depicted in the story. The ultimate end is to win over the minds of the people. With a focus on the depiction of Germany's psychological domination over the British people and the attempts by the British to prevent it, to add exciting military battle scenes would be a distraction. In the fictional German occupation, the very nature of modern war is revealed through Munro's imagination.

\section{The Propaganda War}

Yeovil returns home to confront a substantially Germanised London, and just a day later, he learns that British citizens are being psychologically attacked. How it is happening is hinted at in the words of his friend Holham: '[the Germans] count on time and tact to

2 The National Service League was founded in 1902 to make conscription legal. Except for the United States, Britain was the only one of the powers without conscription. The aim of conscription was to be competitive with other powerful countries. The organisation welcomed the war hero Frederick Roberts as president in 1905. The League, which had only 2000 members at that time, greatly increased its membership to about 100,000 by 1913. It became the largest political organisation in Britain. However, they failed to make peacetime universal conscription legal. For more information, see Roger. T. Stearn's The National Service League: Lord Roberts and the campaign for compulsory military training (Stearn 2006). 
weaken and finally obliterate the old feelings of nationality' (p. 53). Yeovil is also made aware that attacks are coming not only from the Germans, but also from some of the Britons, including his wife Cecily. Herr von Kwarl, the mastermind of the occupation strategy, uses sports and the arts to manipulate the British public into reducing their hostility towards Germany and by doing so guides them to accept the new ruler. According to such a strategy, Cecily encourages him to live a comfortable life with his hobbies, such as hunting, so that he will forget the disruption caused by the defeat and gradually get used to the German regime. Von Kwarl's strategy does not rely solely on luring. He also knows that the large German fleet in the surrounding seas is a good reminder for the British that a counterattack is hopeless; it is a carrot-and-stick approach. Von Kwarl is confident that, even if the German troops in Britain are wiped out, Germany, which is in control of the surrounding seas, will be able to reoccupy Britain within three weeks. Such a strategy of German occupation seems powerful enough to subdue many rational people. However, as he admits, there is a possible flaw in the strategy:

[T]he younger generation of Britons may grow up in hereditary hatred, repulsing all our overtures, forgetting nothing and forgiving nothing, waiting and watching for the time when some weakness assails us, when some crisis entangles us, when we cannot be everywhere at once. Then our work will be imperilled, perhaps undone. There lies the danger, there lies the hope, the younger generation.

He does not think these rational thinkers are a threat. He is concerned about the younger generation, and the quote clearly shows his intention of winning over the minds of the younger generation in Britain. It is clear from the actions and thoughts of Greymarten and Kerrick that the British side is also aware of the importance of the younger generation. The novel begins after Britain's complete military defeat, but the war of the two races has not yet ended. The war of winning over the minds of subjugated people, especially younger ones, still continues. In other words, what is happening in the novel is the fighting of a propaganda war.

The story depicts the progress of the German psychological conquest mostly from Yeovil's point of view, and Yeovil himself gradually accepts German domination. In the course of the story, the reader can experience the nature of sophisticated propaganda through his struggles. The final chapter is about the review of a Boy Scout march in the presence of the German Emperor and other prominent figures. The Boy Scouts are the only remaining military-related organisation in the story. The purpose of this event is to lure British young people to the German side. Winning them over is precisely the purpose of the propaganda war waged by von Kwarl and Greymarten. The importance of the event is told by the Countess of Bailquist, one of the most important figures in the British society and a major shareholder in a newspaper called Dawn: 'If it miscarries it will be a serious set-back for the fait accompli. If it is a success it will be the biggest step forward in the path of reconciliation between the two races that has yet been taken' (p. 308). This influential character in the media gives high importance to this event. It is not an exaggeration to say that this psychological battle will decide the war between Britain and Germany.

Gräfin von Tolb, another prominent German figure in London society, also tells of the importance of this event, but from a different viewpoint: 'It is most important that we should consolidate our position in this country; we must coax the younger generation over by degrees, we must disarm their hostility. We cannot afford to be always on the watch in this quarter; it is a source of weakness, and we cannot afford to be weak' (pp. 314-5). Unlike Bailquist, von Tolb is not focusing here on the beautiful idealism of the unity of the two races, but rather on the strategy from the rulers' point of view: the stability of rulership. This scene is the climax of the novel and the decisive battle of the propaganda war; hence, it is treated accordingly. It is described as follows:

Through the archway at Hyde Park Corner came a resplendent cavalcade, with a swirl of colour and rhythmic movement and a crash of exultant music; life-guards 
with gleaming helmets, a detachment of Würtemberg lancers with a flutter of black and yellow pennons, a rich medley of staff uniforms, a prancing array of princely horsemen, the Imperial Standard, and the King of Prussia, Great Britain, and Ireland, Emperor of the West. It was the most imposing display that Londoners had seen since the catastrophe.

It seems that Germany prepared everything they could afford for this occasion, and since so much dignity depends on this event, there is no room for failure. When Tolb says, 'Within the next ten years, sooner perhaps, we shall be faced with a crisis which will be only a beginning' (p. 315), it is suggested that the Germans do not have much time left to gain full control of Britain. To ensure their success, the Boy Scouts are promised plenty of rewards and tax benefits in return. Nonetheless, the Boy Scouts do not show up at the assembly point. This failure of the event suggests that the conquest of Britain is unsuccessful and the occupation will likely end soon. In other words, the British side has won this psychological battle. The scene of that victory is described as follows:

The younger generation had barred the door.

And in the pleasant May sunshine the Eagle standard floated and flapped, the black and yellow pennons shifted restlessly, Emperor and Princes, Generals and guards, sat stiffly in their saddles, and waited. And waited.

While reasonable and rational British people have accepted German domination, the younger ones have refused to take the privileges given by Germany, which means that no obedience can be expected from them. It could be said that those who act reasonably are more likely to accept German rule. In other words, the more intelligent and reasonable you think you are, the more likely you are to be manipulated. The majestic rulers depicted here are undoubtedly the losers, and the more they are shown as majestic, the more humorous they look. In the final scene, there is a man who appears to be Yeovil watching this victory: 'Shame, the choking, searing shame of self-reproach that cannot be reasoned away, was dominant in his heart' (p. 322). The British pride that lies within him is awakened and he is overwhelmed by emotions that are 'reasoned away'. Here again, Munro shows another example of the powerlessness of reason.

Unlike the real First World War, the war in this novel begins suddenly and is decided in a very short time. This was rather a common prediction at the time and, naturally, Munro understood it in this way. So, there is no wartime propaganda depicted in the novel. However, what Munro primarily depicts in the story is a consistent propaganda war from the individual to the political level. The way he describes the Germans, who skilfully lead the British to change into a dependent people, must have come from experiencing as a news reporter that no real victory can come without winning public opinion. If considered in that way, a review of this novel in The Westminster Gazette ${ }^{3}$ seems to be missing the point:

It is true that this refusal of our young hopefuls might in that instance be taken as a portent to the German occupation, but we, like the Emperor sat stiffly in our saddles, and waited. When we had waited long enough, and found that there was really nothing left but to read the advertisements of other books that followed.

(Saki's New Novel 1913, p. 15)

The writer of this review points out that the ending is unsatisfactory, as this only ends up showing the potential for youth resistance. However, if it is understood that the novel,

\footnotetext{
3 This is Munro's reply to a review of When William Came in the Westminster Gazette, which states, 'And deep within the heart of the democracy we see a feeble spirit of expediency, a willingness to take the best that is offered, a failure of that splendid initiative which should have hoisted William with a home-made petard' (Saki's New Novel 1913, p. 15).
} 
from beginning to end, is about a propaganda battle, a war that is fought under the surface, then the final chapter can also be understood as a thrilling one.

\section{Conclusions}

Considering this work as the story of a propaganda war between Britain and Germany opens up a new understanding of it. This is different from the studies and criticisms of the novel as advocating for conscription or looking to the military for a breakthrough in British stagnation. As in the study of A. J. Lambert, this novel 'is not in essence a merely patriotic book; it is rather a study in the decay of moral fibre' (Lambert 1976, p. 49); or, as Rau argues, 'the enemy is often not the modern foreign invader but the legacy of empire and affluence that manifests itself in degeneration and complacency' (Rau 2009). Unlike what these quotations suggest, it can be read as a book of vigorous warnings against a clever and fierce propaganda war to come. Moreover, Munro once commented that his intention was not to attack Britons: 'I gave the obvious reasons which would prevent a "home-made petard" from doing permanent damage to anyone but its engineers' (Munro 1913, p. 3).

Yeovil is new to the German regime, as he has recently come back from Siberia. Like the reader, he does not know much about life in Germanic London. The story mostly proceeds from Yeovil's viewpoint, which allows the reader to experience the aftermath of the war from his perspective. The narrative details the process by which Yeovil becomes apathetic to his mother country and devotes his time to the pleasures of everyday life, showing sympathy towards the inevitable result of accepting the German regime. It is therefore questionable whether a large part of the story is intended to criticise those who embrace German domination; and yet, there is no doubt that Munro was criticising many people living in Britain at the time, including Plarsey, who is said to have been an older version of Reginald (Langguth 1981, p. 230). In this novel, which is primarily about London after the defeat, who can criticise Yeovil for indulging in riding, hunting and other pleasures of country life? And why did this piece condemn blind patriots like the fisherman? The solution offered by Greymarten is so laborious a procedure that it is no wonder Yeovil does not bite the bullet. It can be thought that Munro tried to describe the mental process of accepting domination very carefully; it can also be thought that the story emphasises the importance of propaganda by bringing to light how psychological defeat can come to even a patriotic mind. It contains a message that true defeat is not determined solely by military force.

Most stories of invasion predict or imagine what weaknesses an enemy might exploit to wage an attack, and When William Came is precisely the kind of work that points out Britain's unpreparedness by detailing the enemy's propaganda strategy. At a time before the First World War, when the importance of propaganda was not widely known, this was a new attempt to show how to deprive people of their patriotism and induce them to accept defeat and a new regime. It is also very creative as an invasion story in its attempt to portray a fictional Germany's policy, not to tell readers how to prepare against military force, but how to be prepared for their propaganda.

Funding: This research was funded by the Japan Society of Promotion of Science, grant number JP19K13123.

Conflicts of Interest: The author declares no conflict of interest.

\section{References}

Atwood, Rodney. 2015. The Life of Field Marshal Lord Roberts. London: Bloomsbury Academic.

Bayley, Susan. 2019. Fictional German Governess in Edwardian Popular Culture: English Responses to German Militarism and Modernity. Literature E History 28: 194-213.

Byrne, Sandie. 2007. The Unbearable Saki: The Work of H. H. Munro. Oxford: Oxford UP.

Chesney, George Tomkyns. 1871. The Battle of Dorking: Reminiscences of a Volunteer. In Blackwood's Edinburgh Magazine. London: William Blackwood and Sons, vol. 109, pp. 539-72. 
Satoru Fukamachi, trans. 2019, Uiriamu ga Kita Toki: Hoentuorerunke ni Sihaisareta Rondon no Monogatari [When William Came: A Story of London under the Hohenzollerns by Saki]. Tokyo: Kokusyo Kankokai.

Johnson, Matthew. 2017. Peace and Retrenchment? The Edwardian Liberal Party, the Limits of Pacifism, and the Politics of National Defence. In Bid for World Power? New Research on the Outbreak of the First World War. Edited by Andreas Gestrich and Hartmut Pogge von Strandmann. Oxford: Oxford UP, pp. 201-20.

Kadoi, Yoshinobu. 2019. Entame Chizu: Osusume Sansatsu [The Entertainment Map: Three Books Recommended. The Asahi Shimbun, September 8.

Lambert, J. W. 1976. The Bodley Head Saki, 5th ed. London: John Lane the Bodley Head.

Langguth, A. J. 1981. Saki: A Life of Hector Hugh Munro with Six Stories Never Before Collected. New York: Simon and Schuster.

Laurie-Fletcher, Danny. 2019. British Invasion and Spy Literature, 1871-1918. Cham: Palgrave Macmillan.

Le Queux, William. 1906. The Invasion of 1910: With a Full Account of the Siege of London. London: Macmillan, Available online: archive.org/details/in.ernet.dli.2015 (accessed on 26 August 2020).

Munro, H. H. 1913. When William Came. Westminster Gazette. December 11. Available online: www.britishnewspaperarchive.co.uk/ viewer/bl/0002947/19131211/025/0003 (accessed on 15 May 2020).

Rau, Petra. 2009. English Modernism, National Identity and the Germans, 1890-1950. Surrey: Ashgate.

Saki, H. H. Munro. 1912. The Chronicles of Clovis. London: John Lane the Bodley Head, Available online: achive.org/details/ chroniclesofclov00sakirich (accessed on 20 June 2020).

Saki, H. H. Munro. 1914. When William Came: A Story of London under the Hohenzollerns. London: John Lane the Bodley Head, Available online: archive.org/details/whenwilliamcame00sakigoog (accessed on 28 August 2020).

Saki's New Novel. 1913. Westminster Gazette. December 6, p. 15. Available online: www.britishnewspaperarchive.co.uk/viewer/bl/00 02947/19131206/116/0015 (accessed on 15 May 2020).

Shee, George R. F. 1901. The Briton's First Duty: the Case for Conscription. London: Grant Richards, Available online: achive.org/details/ britonsfirstdut00sheegoog (accessed on 28 August 2020).

Stearn, Roger T. 2006. The National Service League: Lord Roberts and the campaign for compulsory military training. Soldier of the Queen: The Journal of the Victorian Military Society 125: 23-31.

Wells, H. G. 1898. The War of the Worlds. London: William Heinemman.

Wodehouse, P. G. 1909. The Swoop!: or How Clarence Saved England. London: Alston Rivers.

Wood, Harry Joseph. 2014. External Threats Mask Internal Fears: Edwardian Invasion Literature 1899-1914. Ph.D. Dissertation, Liverpool U, Liverpool, UK. Available online: livrepository.liverpool.ac.uk/2003341/1/WoodHar_May2014.pdf (accessed on 30 August 2020). 